\title{
Rice husk substrates and pruning time for gypsophila production
}

\section{Sustratos de cascarilla de arroz y momento de la poda en la producción de gypsophila}

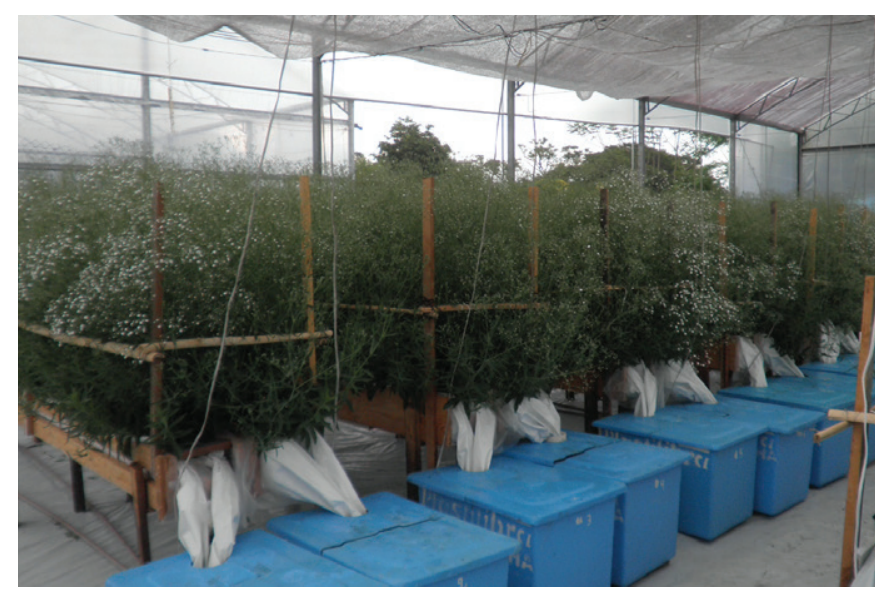

DANIELA HÖHN ${ }^{1,4}$

ROBERTA MARINS NOGUEIRA PEIL ${ }^{1,2}$

LAIS PERIN ${ }^{1}$

PRISCILA MONALISA MARCHI'

PAULO ROBERTO GROLLI

ALBERTINA RADTKE WIETH ${ }^{3}$

Gypsophila production in gutters with leaching recirculation.

Photo: D. Höhn

\section{ABSTRACT}

This research evaluated the growth, yield and quality of gypsophila New Amore ${ }^{\circledR}$ variety grown in gutters filled with substrate in a system with leaching recirculation in southern Brazil. The treatments were the result of the combination of four substrates [carbonized rice husk (CRH100\%), raw rice husk (RRH100\%), $\mathrm{CRH}+$ organic commercial substrate S10 $\left(\right.$ Beifort $\left.^{\circledR}\right)(15 \%)$ and RRH+S10 (15\%)] with two pruning times (early and late). The substrates did not affect the dry matter partitioning between the flowers and vegetative organs or the balance between the shoot and root growth. However, RRH100\% reduced the shoot growth, flower stem yield and quality. The CRH100\% and RRH+S10 substrates can be indicated for gypsophila cultivation once, in a general way, they presented promising results. The late pruning increased the gypsophila growth and yield and benefited the quality of the stems. The gypsophila plants adapted well to the employed crop system.

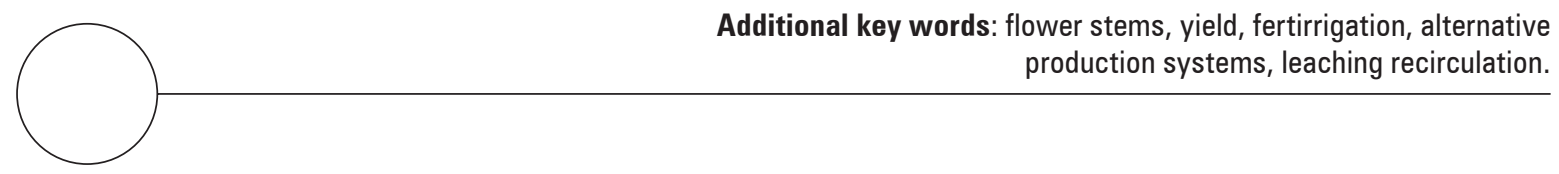

\footnotetext{
1 Capão do Leão, Federal University of Pelotas (UFPEL), Rio Grande do Sul-RS (Brazil). ORCID Höhn, D.: 0000-0001-7280-046X; ORCID Peil, R.M.N.: 0000-0002-4855-3638; ORCID Perin, L.: 0000-0003-4886-9664; ORCID Marchi, P.M.: 0000-0001-7505-1142; ORCID Grolli, P.R.: 0000-0002-5695-9072

2 CNPq (Brazilian National Research Council), Researcher.

${ }^{3}$ Federal University of Rio Grande do Sul (UFRGS), Porto Alegre, Rio Grande do Sul-RS (Brazil). ORCID Wieth, A.R.: 0000-0002-4401-8603

${ }^{4}$ Corresponding author.dani.hohn.sc@gmail.com
} 


\section{RESUMEN}

El objetivo de esta investigación fue evaluar el crecimiento, productividad y calidad de gypsophila variedad New Amore $^{\circledR}$, cultivada en canales rellenos con sustratos y sistema con recirculación de la solución nutritiva en el sur de Brazil. Los tratamientos fueron el resultado de la combinación de cuatro sustratos [cascarilla de arroz carbonizada (CAC100\%), cascarilla de arroz cruda (CACr100\%), CAC + sustrato comercial orgánico S10 (Beifort $\left.{ }^{\circledR}\right)(15 \%)$ y CA$\mathrm{Cr}+\mathrm{S} 10(15 \%)]$ y dos épocas de poda (precoz y tardía). Los sustratos no afectaron la distribución de la materia seca entre las flores y los órganos vegetativos, así como el balance entre el crecimiento de la parte aérea y de las raíces. Sin embargo, el cultivo en el sustrato CACr100\% redujo el crecimiento de la parte aérea, la producción y la calidad de los tallos florales. Los sustratos CAC100\% y CACr+S10 pueden ser indicados para el cultivo de gypsophila debido a los buenos resultados obtenidos. La poda tardía aumentó el crecimiento, la productividad y mejoró la calidad de los tallos florales de gypsophila. Se concluye que las plantas de gypsophila se adaptaron bien al sistema de cultivo con recirculación de la solución nutritiva.

Palabras clave adicionales: tallos florales, productividad, fertirriego, sistemas alternativos de producción, recirculación de la solución.

Received for publication: 21-03-2018 Accepted for publication: 30-05-2018

INTRODUCTION

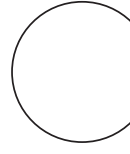

Gypsophila paniculata, popularly known as baby's-breath, is widely used in floral arrangements and bouquets, cultivated as an annual cut flower (Petry, 2008). Gypsophila has a reduced life cycle because of its susceptible to soil pathogens (Wahome et al., 2011). Cultivation in a substrate, beyond avoiding pathogens, may allow gypsophila production in areas where its cultivation is difficult or impractical.

Among the materials used as the substrate component for ornamental plants cultivation, carbonized rice husks present some positive characteristics, such as high porosity, allowing drainage and aeration, good sanitary aspects (Ferreira et al., 2008), low cost and easy acquisition (Da Costa et al., 2017). However, there are some drawbacks in the carbonization process since it is onerous, presents low efficiency and causes air pollution.

In this sense, raw rice husks can be an alternative substrate in nutrient solution recirculation systems ("closed systems"). In this system, the high leaching of the nutrient solution as a result of the low water holding capacity of raw rice husks does not represent an environmental problem because of the leach reuse (Peil et al., 2014).

Flower cultivation in substrates with leaching recirculation may be a promising crop growing system because it saves water and fertilizer and presents less of an environmental impact. However, the use of closed systems requires a proper substrate. The high proportion of organic compound in the mixture means a high CEC, making impossible to adopt this practice because of the tendency towards salinization. On the other hand, the absence of organic compounds in rice husk mixtures can lead to water deficit problems because of the resulting low water holding capacity (Steffen et al., 2010).

Besides the aspects related to the cultivation system, crop management is another fundamental element for determining plant yield and quality. The apical pruning of gypsophila plants ("pinching") consists of eliminating their apex in the first productive cycle in order to break the apical dominance and increase yield (Dorajeerao and Mokashi, 2013). Late pruning could benefit the initial establishment of the crop, with positive effects on plant growth and final yield of stems.

Studies focusing on the substrate in closed growing systems and the pruning time are still non-existent for gypsophila. Thus, the goal of this research was to verify the adaptation of gypsophila crops to gutters filled with substrate in a system with leaching recirculation. The effects of rice husk-based substrates and 
two pruning times (early and late) on plant growth and flower stem quality and yield were considered.

\section{MATERIAL AND METHODS}

The trial was conducted in a plastic greenhouse $(10 \times 18 \mathrm{~m})$ at the Capão do Leão-RS from October $7^{\text {th }}, 2015$ to April $4^{\text {th }}, 2016$. The approximate geographic location is $31^{\circ} 52^{\prime} \mathrm{S}$ and $52^{\circ} 21^{\prime} \mathrm{W}$ at an altitude of $13 \mathrm{~m}$. The air temperature was monitored with a digital thermo-hygrometer installed in a meteorologi$\mathrm{cal}$ shelter. The mean medium, maximum and minimum temperatures were, respectively, $24.1^{\circ} \mathrm{C}, 29.8^{\circ} \mathrm{C}$ and $18.5^{\circ} \mathrm{C}$.

The New Amore ${ }^{\circledast}$ variety was used and the transplant was carried out on October $7^{\text {th }}$, 2015, when the commercial seedlings were about 4 to $5 \mathrm{~cm}$ high.

The cultivation system consisted of 12 wooden gutters (3.50 m long and $0.20 \mathrm{~m}$ wide), arranged in six double rows sloping $3 \%$. The pairs of double rows were $0.80 \mathrm{~m}$ apart $(0.60 \mathrm{~m}$ wide paths $)$ with a 0.25 $\mathrm{m}$ between-row distance. The gutters were internally waterproofed with a white polyethylene film in order to collect and return the drain solution to a $100 \mathrm{~L}$ catchment tank placed at the final part of each gutter, forming a closed system. The substrates were arranged directly in the gutters with a $0.15 \mathrm{~m}$ high layer, corresponding to a volume of $105 \mathrm{~L} /$ gutter, which resulted in $5.8 \mathrm{~L} /$ plant, approximately.
A low-power washing machine pump was installed in each catchment tank. Fertirrigation was performed using drip tapes with a spacing of $0.20 \mathrm{~m}$ and an approximate flow rate of $8.0 \mathrm{~L} \mathrm{~h}^{-1}$. The nutrient solution was supplied intermittently, with a $15 \mathrm{~min}$ supply every hour, from 7 am to $7 \mathrm{pm}$.

The formulation of the nutrient solution followed the recommendation of Sonneveld and Straver (1994), whose composition of macronutrients was (in $\mathrm{mmol} \mathrm{L}^{-1}$ ): 15.0 of $\mathrm{NO}_{3}^{-} 1.7$ of $\mathrm{H}_{2} \mathrm{PO}_{4}{ }^{-} ; 1.5$ of $\mathrm{SO}_{4}{ }^{2-}$; 1.2 of $\mathrm{NH}_{4}^{+} ; 7.0$ of $\mathrm{K}^{+}$; 4.5 of $\mathrm{Ca}^{2+} ; 1.2$ of $\mathrm{Mg}^{2+}$; and micronutrients (in $\mathrm{mg} \mathrm{L}^{-1}$ ): 1.40 of Fe; 0.6 of $\mathrm{Mn} ; 0.30$ of $\mathrm{Zn} ; 0.30$ of $\mathrm{B} ; 0.05$ of $\mathrm{Cu}$ and 0.05 of Mo. The electrical conductivity (EC) was maintained between 1.7 and $1.9 \mathrm{dS} \mathrm{m}^{-1}$ and the $\mathrm{pH}$ between 5.5 and 6.5 .

Four substrates were used: carbonized rice husk (CRH100\%) and raw rice husks (RRH100\%), used alone, and mixtures with $\mathrm{CRH}(85 \%)+$ commercial organic compound $\mathrm{S} 10^{\circledR}$ (Beifort, Garbaldi-RS, Brazil) $(15 \%)$ or RRH $(85 \%)+\mathrm{S} 10^{\circledast}(15 \%)$. The commercial organic compound $\mathrm{S} 0^{\oplus}$ originates from the composting of grape stalks and marc. The physical and chemical characteristics of the substrates were determined in the laboratory (Tab. 1).

Spacing the plants at $0.20 \mathrm{~m}$ in the within-row distance provided a plant density of 10.8 plants $/ \mathrm{m}^{2}$, totaling 18 plants per gutter and 216 plants in total. At 21 days after setting (das), apical pruning was carried out in half of the plants of each gutter. The

Table 1. Physical and chemical characteristics of the substrates carbonized rice husk (CRH) and raw rice husk (RRH), used alone and in mixture with the commercial $\$ 10$ organic compound (Beifort ${ }^{\circledR}$ ) at a $15 \%$ ratio, for the cultivation of Gypsophila paniculata in gutters with leaching recirculation.

\begin{tabular}{|c|c|c|c|c|}
\hline \multirow{2}{*}{ Physical characteristics } & \multicolumn{4}{|c|}{ Substrates } \\
\hline & $\mathrm{CRH}$ & $\mathrm{RRH}$ & $\mathrm{CRH}+\mathrm{S} 10$ & $\mathrm{RRH}+\mathrm{S} 10$ \\
\hline Wet density $\left(g \mathrm{~L}^{-1}\right)$ & 262 & 236 & 343 & 417 \\
\hline Dry matter $(\mathrm{g} / 100 \mathrm{~g})$ & 60 & 38 & 54 & 54 \\
\hline Dry density $\left(\mathrm{g} \mathrm{L}^{-1}\right)$ & 156 & 90 & 186 & 225 \\
\hline Total porosity $\left(\mathrm{m}^{3} \mathrm{~m}^{-3}\right)$ & 0.77 & 0.72 & 0.74 & 0.76 \\
\hline Aeration space $\left(\mathrm{m}^{3} \mathrm{~m}^{-3}\right)$ & 0.56 & 0.58 & 0.47 & 0.42 \\
\hline Water easily available $\left(\mathrm{m}^{3} \mathrm{~m}^{-3}\right)$ & 0.12 & 0.04 & 0.12 & 0.12 \\
\hline Water holding capacity in $10 \mathrm{~cm}\left(\mathrm{~m}^{3} \mathrm{~m}^{-3}\right)$ & 0.20 & 0.14 & 0.27 & 0.35 \\
\hline \multicolumn{5}{|l|}{ Chemical characteristics } \\
\hline Electrical conductivity ( $\left.\mathrm{dS} \mathrm{m}^{-1}\right)$ & 0.11 & 0.07 & 0.26 & 0.51 \\
\hline $\mathrm{pH}$ value $\left(\mathrm{H}_{2} \mathrm{O}\right)$ & 5.06 & 5.29 & 5.00 & 4.69 \\
\hline
\end{tabular}


primary stem apex was removed. In the remaining plants, pruning was performed at 42 das. Thus, two pruning times were established, early and late pruning, respectively.

A randomized block experiment design with subdivided plots and three replications was used. The substrate was allocated in the plot (corresponding to a gutter with 18 plants) and pruning time in the subplot (9 plants).

The harvest started at 88 das, on January $5^{\text {th }}, 2016$, and ended at 96 das in the first productive cycle. The second productive cycle started at 171 das, on March $27^{\text {th }}, 2016$, and ended at 180 das. Flower stems longer than $50 \mathrm{~cm}$ were collected when about $30 \%$ open flower buds was presented.

Four plants per subplot were selected for the evaluation of the following variables:

(a) Productivity variables: the number and the fresh weight of the productive flower stems were evaluated. With these data, the flower stem average weight, the yield and the number of packs (300 g) harvested per square meter were calculated.

(b) Quality variables: the following variables were evaluated: stem length $(\mathrm{cm})$ and diameter $(\mathrm{mm}$; obtained by measuring the flower stems base with a pachymeter) and the number of side branches (branches more than $10 \mathrm{~cm}$ long originating from the main axis of each productive flower stem were counted).

(c) Plant dry matter: the productive flower stems were separated into vegetative and flowers fractions. At the end of the experiment, the remains of the crop were collected. The roots were separated from the substrate with washing using low pressure running water. The different fractions were dried in an oven at $65^{\circ} \mathrm{C}$ until constant weight to obtain the dry matter (DM). The shoot dry matter partitioning was calculated for each productive cycle. The sum of the two productive cycle shoot organ DM production and the root DM obtained at the end of the experiment were considered in order to determine the shoot/root DM ratio.

The data were submitted to analysis of variance and comparison of means with Tukey's test at $5 \%$ probability.

\section{RESULTS AND DISCUSSION}

The interaction between the substrate and pruning time was not significant for any of the evaluated variables. Therefore, the results were interpreted separately for each experiment factor (Tab. 2, 3 and 4).

For the effect of the substrates on the plant shoot growth (Tab. 2), CRH + S10 promoted a higher shoot DM production, but it did not differ significantly from RRH+S10 and CRH100\%. The substrate $\mathrm{RRH} 100 \%$ presented lower results than $\mathrm{CRH}+\mathrm{S} 10$.

In the first productive cycle, the use of $\mathrm{CRH}+\mathrm{S} 10$ increased the vegetative and the total shoot DM production, as compared to the substrate RRH $100 \%$. In the second productive cycle, CRH $100 \%$ promoted higher values of vegetative and total shoot DM production in comparison to RRH100\%. The addition of S10 to RRH did not show significant positive effects on any of the growth variables analyzed in both productive cycles. However, although there were no significant differences between CRH100\% and $\mathrm{CRH}+\mathrm{S} 10$ in relation to thee vegetative and flower $\mathrm{DM}$, as a result of the highest values for both variables, the $\mathrm{CRH}+\mathrm{S} 10$ combination increased the DM production of the shoot in the first cycle. However, it had no effects in the second cycle. No significant effects from the substrates on the flower DM production and DM partitioning between the different organs of the shoot in both productive cycles were observed (Tab. 2).

For the pruning time, the results showed that, in both productive cycles, the late pruning provided a higher DM production of flowers (Tab. 2). Since the vegetative DM production was not affected, the late pruning increased the DM partitioning to the flowers (20.3 and $18.8 \%$ ) in comparison to the early pruning (12.9 and 14.5\%) in the first and second cycles, respectively. These results indicate that the late pruning promoted a greater proportion of flowers in the shoot, which is primordial from the ornamental point of view.

On average, the flowers comprised only $16.7 \%$ of the total shoot DM production, which demonstrated that they are low sinks for assimilates, regardless of the analyzed treatment.

With respect to the variables related to root growth (Tab. 3), the only observed difference was the higher root DM production of the plants cultivated in 
Table 2. Effect of substrate and pruning time on the dry matter production and partitioning between vegetative plant organs and flowers of Gypsophila paniculata cultivated in gutters with leaching recirculation.

\begin{tabular}{|c|c|c|c|c|c|}
\hline & \multicolumn{3}{|c|}{ Dry matter production (g/plant) } & \multicolumn{2}{|c|}{ Dry matter partitioning (\%) } \\
\hline & Vegetative & Flowers & Shoot & Vegetative & Flowers \\
\hline Effect & \multicolumn{5}{|c|}{ First productive cycle } \\
\hline Substrate & & & & & \\
\hline $\mathrm{CRH}$ & $53.0 \mathrm{ab}$ & $10.5 \mathrm{a}$ & $64.0 \mathrm{~b}$ & 82.9 a & $17.1 \mathrm{a}$ \\
\hline $\mathrm{RRH}$ & $43.5 b$ & $9.0 \mathrm{a}$ & $52.5 b$ & $82.5 \mathrm{a}$ & $17.5 \mathrm{a}$ \\
\hline $\mathrm{CRH}+\mathrm{S} 10$ & $68.0 \mathrm{a}$ & $13.0 \mathrm{a}$ & $81.5 \mathrm{a}$ & $83.4 \mathrm{a}$ & $16.6 \mathrm{a}$ \\
\hline $\mathrm{RRH}+\mathrm{S} 10$ & $57.0 \mathrm{ab}$ & $11.2 \mathrm{a}$ & $68.2 \mathrm{ab}$ & $83.7 \mathrm{a}$ & $16.3 \mathrm{a}$ \\
\hline \multicolumn{6}{|l|}{ Pruning } \\
\hline Early (21 das) & 54.9 a & $7.7 \mathrm{~b}$ & $62.9 \mathrm{a}$ & $87.1 \mathrm{a}$ & $12.9 \mathrm{~b}$ \\
\hline Late (42 das) & 55.8 a & $14.1 \mathrm{a}$ & $70.6 \mathrm{a}$ & 79.7 b & $20.3 \mathrm{a}$ \\
\hline CV \% & 19.32 & 26.66 & 19.87 & 3.09 & 15.74 \\
\hline & \multicolumn{5}{|c|}{ Second productive cycle } \\
\hline \multicolumn{6}{|l|}{ Substrate } \\
\hline $\mathrm{CRH}$ & $43.3 \mathrm{a}$ & $8.8 \mathrm{a}$ & $52.1 \mathrm{a}$ & $83.2 \mathrm{a}$ & $16.8 \mathrm{a}$ \\
\hline $\mathrm{RRH}$ & $32.2 \mathrm{~b}$ & $6.7 \mathrm{a}$ & $38.9 \mathrm{~b}$ & $82.8 \mathrm{a}$ & $17.2 \mathrm{a}$ \\
\hline $\mathrm{CRH}+\mathrm{S} 10$ & $40.2 \mathrm{ab}$ & $7.8 \mathrm{a}$ & $48.0 \mathrm{ab}$ & $83.7 \mathrm{a}$ & $16.3 \mathrm{a}$ \\
\hline $\mathrm{RRH}+\mathrm{S} 10$ & $39.8 \mathrm{ab}$ & $7.7 \mathrm{a}$ & $47.5 \mathrm{ab}$ & $83.8 \mathrm{a}$ & $16.2 \mathrm{a}$ \\
\hline \multicolumn{6}{|l|}{ Pruning } \\
\hline Early & $37.3 \mathrm{a}$ & $6.0 \mathrm{~b}$ & $43.3 \mathrm{~b}$ & $85.5 \mathrm{a}$ & $14.5 \mathrm{~b}$ \\
\hline Late & 40.7 a & $9.5 \mathrm{a}$ & $50.5 \mathrm{a}$ & $81.2 b$ & $18.8 \mathrm{a}$ \\
\hline CV \% & 14.9 & 24.61 & 15.4 & 3.46 & 17.4 \\
\hline
\end{tabular}

CRH: carbonized rice husk; RRH: raw rice husk; S10: comercial organic compound (Beifort $\left.{ }^{\circledR}\right)$ at the ratio of $15 \%$ in the substrate mixture.

Means followed by the same letter in the column, for each factor and productive cycle, do not differ significantly according to the Tukey test $(P \leq 0.05)$.

$\mathrm{RRH}+\mathrm{S} 10$, as compared to the RRH100\% substrate. Despite this difference, the substrates had no effect on the shoot/root DM ratio. Thus, we can say that the plants cultivated in the four substrates showed a proper balance between root activity (water and nutrient uptake) and shoot activity (photosynthesis). The pruning time did not have a significant effect on the root DM production or the shoot/root DM ratio (Tab. 3).

The substrates had no significant effect on the variables related to the quality of the flower stems in the first cycle (Tab. 4). In the second cycle, the cultivation in $\mathrm{CRH}+\mathrm{S} 10$ increased the plant stems diameter, as compared to RRH100\% (Tab. 4). However, no effect of substrates was observed on the flower stem length and number of side branches per stem.

For the productivity variables in the first cycle, the $\mathrm{CRH}+\mathrm{S} 10$ substrate increased the flower stem average weight in relation to the cultivation in both
Table 3. Effect of substrate and pruning time on the root dry matter production and the ratio of shoot/root dry matter of Gypsophila paniculata cultivated in gutters with leaching recirculation.

\begin{tabular}{|c|c|c|}
\hline & $\begin{array}{c}\text { Dry matter of roots } \\
\text { (g/plant) }\end{array}$ & $\begin{array}{l}\text { Shoot-root ratio } \\
\qquad\left(\mathrm{g} \mathrm{g}^{-1}\right)\end{array}$ \\
\hline \multicolumn{3}{|l|}{ Substrate } \\
\hline $\mathrm{CRH}$ & $8.3 \mathrm{ab}$ & $14.6 \mathrm{a}$ \\
\hline $\mathrm{RRH}$ & $6.0 \mathrm{~b}$ & $15.8 \mathrm{a}$ \\
\hline $\mathrm{CRH}+\mathrm{S} 10$ & $7.5 a b$ & $18.2 \mathrm{a}$ \\
\hline $\mathrm{RRH}+\mathrm{S} 10$ & $8.7 \mathrm{a}$ & $14.2 \mathrm{a}$ \\
\hline \multicolumn{3}{|l|}{ Pruning } \\
\hline Early (21 das) & $7.6 \mathrm{a}$ & $14.6 \mathrm{a}$ \\
\hline Late (42 das) & $7.7 \mathrm{a}$ & $16.8 \mathrm{a}$ \\
\hline CV\% & 18.2 & 20.9 \\
\hline
\end{tabular}

CRH: carbonized rice husk; RRH: raw rice husk; S10: comercial organic compound $\left(\right.$ Beifort $\left.^{\circledR}\right)$ at the ratio of $15 \%$ in the substrate mixture.

Means followed by the same letter in the column, for each factor, do not differ significantly according to the Tukey test $(P \leq 0.05)$. 
Table 4. Effect of substrate and pruning time on the flower stem quality and productivity responses of Gypsophila paniculata cultivated in gutters with leaching recirculation.

\begin{tabular}{|c|c|c|c|c|c|c|c|}
\hline & \multicolumn{3}{|c|}{ Ouality Variables } & \multicolumn{4}{|c|}{ Productivity } \\
\hline & $\begin{array}{l}\text { Stem diameter } \\
(\mathrm{mm})\end{array}$ & $\begin{array}{l}\text { Stem lengh } \\
\quad(\mathrm{cm})\end{array}$ & $\begin{array}{l}\mathrm{N}^{0} \text { of side } \\
\text { branches/ } \\
\text { stem }\end{array}$ & $\begin{array}{c}\text { Stem average } \\
\text { weight }(\mathrm{g})\end{array}$ & $\begin{array}{c}\mathrm{N}^{0} \text { of stems } \\
\left(\mathrm{m}^{-2}\right)\end{array}$ & $\begin{array}{l}\text { Stem yield } \\
\qquad\left(\mathrm{g} \mathrm{m}^{-2}\right)\end{array}$ & $\begin{array}{c}\mathrm{N}^{0} \text { of packs } \\
\left(\mathrm{m}^{-2}\right)\end{array}$ \\
\hline \multicolumn{8}{|c|}{ First productive cycle } \\
\hline \multicolumn{8}{|l|}{ Substrate } \\
\hline $\mathrm{CRH}$ & $4.6 \mathrm{a}$ & $89.5 \mathrm{a}$ & $9.1 \mathrm{a}$ & $24.3 b$ & $103.5 \mathrm{a}$ & $2,418.0 a b$ & $8.0 a b$ \\
\hline $\mathrm{RRH}$ & $4.5 \mathrm{a}$ & $87.3 \mathrm{a}$ & $9.3 \mathrm{a}$ & $23.4 b$ & $90.4 \mathrm{a}$ & $1,906.3 b$ & $6.4 b$ \\
\hline $\mathrm{CRH}+\mathrm{S} 10$ & $4.6 \mathrm{a}$ & $93.4 \mathrm{a}$ & $9.7 \mathrm{a}$ & $34.55 a$ & $93.6 \mathrm{a}$ & $3,076.1 \mathrm{a}$ & $10.2 \mathrm{a}$ \\
\hline $\mathrm{RRH}+\mathrm{S} 10$ & $4.7 \mathrm{a}$ & $89.7 \mathrm{a}$ & $9.6 \mathrm{a}$ & $28.6 \mathrm{ab}$ & $91.8 \mathrm{a}$ & $2,528.0 \mathrm{ab}$ & $8.5 a b$ \\
\hline \multicolumn{8}{|l|}{ Pruning } \\
\hline Early & $5.0 \mathrm{a}$ & $86.6 \mathrm{~b}$ & $10.3 \mathrm{a}$ & $32.7 \mathrm{a}$ & $73.3 b$ & $2,372.7 \mathrm{a}$ & $7.9 \mathrm{a}$ \\
\hline Late & $4.2 \mathrm{~b}$ & $93.4 \mathrm{a}$ & $8.6 b$ & $22.7 b$ & $116.3 \mathrm{a}$ & $2,596.7 \mathrm{a}$ & $8.6 \mathrm{a}$ \\
\hline CV \% & 5.72 & 5.25 & 5.38 & 21.3 & 12.94 & 16.78 & 16.78 \\
\hline \multicolumn{8}{|c|}{ Second productive cycle } \\
\hline \multicolumn{8}{|l|}{ Substrate } \\
\hline $\mathrm{CRH}$ & $4.7 \mathrm{ab}$ & 79.6 a & $11.8 \mathrm{a}$ & $27.2 \mathrm{a}$ & $68.4 \mathrm{a}$ & $1,851.5 \mathrm{a}$ & $6.2 \mathrm{a}$ \\
\hline $\mathrm{RRH}$ & $4.5 b$ & $80.7 \mathrm{a}$ & $11.3 \mathrm{a}$ & $27.8 \mathrm{a}$ & $50.4 b$ & $1,379.4 \mathrm{a}$ & $4.6 \mathrm{a}$ \\
\hline $\mathrm{CRH}+\mathrm{S} 10$ & $5.0 \mathrm{a}$ & $82.9 \mathrm{a}$ & $11.9 \mathrm{a}$ & $31.7 \mathrm{a}$ & $63.0 \mathrm{a}$ & 1,995.1 a & $6.6 \mathrm{a}$ \\
\hline $\mathrm{RRH}+\mathrm{S} 10$ & $4.6 \mathrm{~b}$ & $81.5 \mathrm{a}$ & $11.5 \mathrm{a}$ & $27.7 \mathrm{a}$ & $65.7 \mathrm{a}$ & 1,816.1 a & $6.0 \mathrm{a}$ \\
\hline \multicolumn{8}{|l|}{ Pruning } \\
\hline Early & $4.6 \mathrm{a}$ & $81.2 \mathrm{a}$ & $11.7 \mathrm{a}$ & $27.0 \mathrm{a}$ & $58.9 \mathrm{a}$ & $1,570.0 \mathrm{~b}$ & $5.2 b$ \\
\hline Late & $4.8 \mathrm{a}$ & $81.1 \mathrm{a}$ & $11.6 \mathrm{a}$ & $30.1 \mathrm{a}$ & $64.8 \mathrm{a}$ & $1,950.9 \mathrm{a}$ & $6.4 \mathrm{a}$ \\
\hline CV \% & 4.1 & 3.61 & 5.82 & 18.26 & 12.12 & 22.48 & 22.48 \\
\hline \multicolumn{8}{|c|}{ Total: $1^{\text {st }}+2^{\text {nd }}$ cycle } \\
\hline \multicolumn{8}{|l|}{ Substrate } \\
\hline CRH100\% & & & & $31.4 \mathrm{a}$ & $171.9 \mathrm{a}$ & $4,269.4 a b$ & $14.3 a b$ \\
\hline RRH100\% & & & & $51.18 \mathrm{a}$ & $140.8 \mathrm{~b}$ & $3,285.7 b$ & $10.9 b$ \\
\hline $\mathrm{CRH}+\mathrm{S} 10$ & & & & $66.2 \mathrm{a}$ & $156.6 \mathrm{ab}$ & $5,071.2 \mathrm{a}$ & $16.8 \mathrm{a}$ \\
\hline $\mathrm{RRH}+\mathrm{S} 10$ & & & & $56.4 \mathrm{a}$ & $157.5 \mathrm{ab}$ & $4,354.6 a b$ & $14.5 \mathrm{ab}$ \\
\hline \multicolumn{8}{|l|}{ Pruning } \\
\hline Early & & & & $59.7 \mathrm{a}$ & $132.3 \mathrm{~b}$ & $3,942.9 \mathrm{a}$ & $13.2 \mathrm{a}$ \\
\hline Late & & & & $52.8 \mathrm{a}$ & $181.1 \mathrm{a}$ & $4,547.6 \mathrm{a}$ & $15.14 \mathrm{a}$ \\
\hline CV \% & & & & 17.05 & 9.22 & 17.14 & 17.2 \\
\hline
\end{tabular}

CRH: carbonized rice husk; RRH: raw rice husk; S10: comercial organic compound (Beifort ${ }^{\oplus}$ ) at the ratio of $15 \%$ in the substrate mixture. Means followed by the same letter in the column, for each factor and cycle, do not differ significantly according to the Tukey test $(P \leq 0.05)$.

RRH100\% and CRH100\%. It also increased the yield of flower stems and the number of packs harvested per square meter in comparison with RRH100\% (Tab. $4)$. In the second productive cycle, the only difference was in the lowest number of stems $/ \mathrm{m}^{2}$, obtained from the plants cultivated in CRH100\% (Tab. 4). Thus, the effects of the addition of compound S10 to improve the productivity responses to the use of pure materials were barely perceptible in both $\mathrm{CRH}$ and RRH. The S10 addition only increased the average 
weight of the flower stems in relation to the use of CRH100\% in the first cycle and increased the number of flower stems harvested per $\mathrm{m}^{2}$ in relation to RRH $100 \%$ in the second cycle.

For the sum of the two productive cycles, the CR$\mathrm{H}+\mathrm{S} 10$ mixture continued to show better results than RRH100\% with respect to the flower stem yield and the number of packs $/ \mathrm{m}^{2}$.

It should be pointed out that, when RRH $100 \%$ was compared to the CRH $100 \%$, the first one did not affect negatively any of the quality variables. It presented a negative effect only in terms of the number of stems $/ \mathrm{m}^{2}$ in the second productive cycle, which remained in the sum of the two cycles (Tab. 4).

The effects of the substrate on the productive variables were more incipient in the second productive cycle than in the first one. Possibly, this can be attributed to the increase in the water holding capacity (WHC) and the higher adsorption of nutrient ions caused by the natural decomposition of the material over time.

The results obtained can be explained according to the characteristics of the substrates (Tab. 1). The addition of S10 at the ratio of $15 \%$ conferred benefits to some of the physical and chemical characteristics of the mixtures as compared to the use of pure materials, especially in $\mathrm{RRH}$.

The RRH, when employed alone, led to some inferior responses in comparison with the other substrates. This fact can be attributed to the low WHC (Tab. 1), which results in difficulty in the conservation of a homogeneous moisture, indicating that it should be used in mixture with other materials in order to obtain greater efficiency. Medeiros et al. (2008) highlighted the trend for lower productivity with RRH, evaluating strawberry cultivation in different rice husk substrates. The low WC of the RRH would negatively influence the yield of the crop because it would hinder the absorption of water and nutrients to the plants.

The addition of S10 considerably increased the wet density of RRH and CRH (Tab. 1). The dry matter content of the substrate increased in the $\mathrm{RRH}+\mathrm{S} 10$ mixture and decreased in $\mathrm{CRH}+\mathrm{S} 10$. However, the total porosity did not change in either substrate. The addition of S10 caused a reduction in the aeration space of the substrates, which was lower in
CRH (9\%) than in RRH (16\%). This led to aeration levels in the range that is considered ideal for horticultural substrates. However, this did not change the easily available water in $\mathrm{CRH}+\mathrm{S} 10$, but increased it in $\mathrm{RRH}+\mathrm{S} 10$. The WHC of the mixtures increased considerably when compared to the pure materials, especially in RRH+S10 (Tab. 1).

The physical changes observed in the substrates caused by the addition of S10 were related to the rearrangement of the particles with the introduction of the material formed by smaller particles (S10), which was more evident in RRH, whose particles have a more uniform size. The carbonization process broke part of the rice husks, which generated greater variation in the particle size distribution in $\mathrm{CRH}$, with a percentage that was similar to the particle size in S10. Thus, the addition of the S10 conditioner affected the physical properties of the CRH less after mixing than RRH.

The addition of S10 increased the EC in the mixtures relative to the pure materials, which was more evident in RRH (Tab. 1). Possibly, S10 released ions in the substrate solution when irrigated with water alone, causing an increase in the EC before plant setting of 0.15 and $0.29 \mathrm{dS} \mathrm{m}^{-1}$, respectively, in $\mathrm{CRH}+\mathrm{S} 10$ and $\mathrm{RRH}+\mathrm{S} 10$, as compared to the pure materials.

For the $\mathrm{pH}$ values, the addition of S10 to RRH reduced this value, but it did not cause a significant change in the $\mathrm{pH}$ of the $\mathrm{CRH}+\mathrm{S} 10$ as compared to CRH100\%. This reduction can be attributed to the presence of S10 microorganisms in combination with the RRH microorganisms, which would influence the substrate composition and, consequently, $\mathrm{pH}$. In this experiment, the lower $\mathrm{pH}$ observed in $\mathrm{RRH}+\mathrm{S} 10$ before the plant cultivation was not detrimental since the corrections made with sodium hydroxide throughout the growing period increased the $\mathrm{pH}$ values and, consequently, the availability of adequate nutrients to the development of the crop.

Thus, changes in the physical and chemical characteristics were more evident with the addition of S10 to $\mathrm{RRH}$ than to $\mathrm{CRH}$, indicating an increase in the availability of water and nutrient content, which could explain the improvement of plant responses in the $\mathrm{RRH}+\mathrm{S} 10$ mixture over RRH100\%.

So, $\mathrm{RRH}+\mathrm{S} 10, \mathrm{CRH} 100 \%$ and $\mathrm{CRH}+\mathrm{S} 10$ presented better results. However, the RRH100\% negative responses were not constant for all of the variables. 
Thus, it is not possible to highlight a substrate with clearly superior responses. But, RRH100\% may be considered as less promising substrate for this crop considering the management adopted in this research. In any case, the growth, production and quality responses were quite positive in relation to what is normally observed for gypsophila. Thus, before discarding RRH100\% as a substrate, further research should be performed to verify fertirrigation management for gypsophila cultivation in this material.

The productivity of this crop is mainly related to the number of flower stems and the number of packs of $300 \mathrm{~g}$ (Ibraflor, 2016) produced per square meter. The average production obtained in this experiment, taking account the production from the two cycles, was 156.7 stems $/ \mathrm{m}^{2}$ and 14.1 packs $/ \mathrm{m}^{2}$, which are well above the total values of 113.2 stems $/ \mathrm{m}^{2}$ and 4.9 packs $/ \mathrm{m}^{2}$ obtained by Girardi et al. (2012) for bottled gypsophila.

The positive results can be attributed to the high fertirrigation frequency used, which favored the plant growth, productivity and quality of the gypsophila. Thus, it was possible to verify that the system provided excellent responses of the plants regardless of the substrate. Researchers point out that the high nutrient solution supply in substrate cultivation increases the productivity and quality of different crops by providing plants with adequate amounts of water and mineral nutrients (Andriolo et al., 2009; Pires, 2009).

Therefore, the use of $\mathrm{CRH}$ alone or $\mathrm{RRH}+\mathrm{S} 10$ can be indicated because of the good responses associated with the lower cost of the first and the ease of preparation of the second. In this analysis, it should be taken into account that $\mathrm{CRH}$ is a low cost material, but difficult to obtain because of the carbonization process. On the other hand, the compound S10 has a higher cost, but its proportion was low in the mixture with RRH, which presents low cost in the southern region of Brazil.

For the pruning time effects in the first productive cycle (Tab. 4), the late pruning contributed to the production of longer stems, while the early pruning provided a larger diameter and number of side branches per stem. In addition, the late pruning increased the number of stems produced to 116.3 stems $/ \mathrm{m}^{2}$, while, in the early pruning, this number was 73.3 stems $/ \mathrm{m}^{2}$. In contrast, the early pruning increased the average weight of flower stems. Thus, in the final calculation, the flower stem yield by weight $\left(\mathrm{g} \mathrm{m}^{-2}\right)$ and number of packs harvested per square meter were not affected by the pruning in this productive cycle.

In the second productive cycle, the late pruning increased the flower stem yield and the number of packs harvested per square meter. However, no pruning effect was observed on the other productivity and quality variables (Tab. 4).

The first cycle provided more elongated stems (mean of $90.0 \mathrm{~cm}$ ) than the second one (mean of $81.2 \mathrm{~cm}$ ). According to Ibraflor (2016), $50 \mathrm{~cm}$ is the minimum length of marketable flower stems; longer stems are more valued. Regardless of the pruning time and the productive cycle, the flower stems obtained from all of the treatments met the long stem market standards required by florists.

Uniformity in the flower stem thickness between the two cycles was observed (stem diameter averages of 4.6 and $4.7 \mathrm{~mm}$, respectively, in first and second cycles). Uniformity in stem thickness contributes to the standardization of packs for markets, benefiting the quality of the final product (Ibraflor, 2016).

The analysis of the sum of the two cycles indicated that the positive effect of the late pruning was only observed in the number of stems $/ \mathrm{m}^{2}$ (Tab. 4).

Since, for quality attributes for markets, length is more important than the diameter of flower stems, the joint analysis of the quality variables with the productivity results indicates that late pruning was more suitable for this crop. This can be attributed to plants presenting a higher number of buds at the time of the late pruning. This led to a larger number of flower stems and longer ones in the first cycle; the latter characteristic is attributable to competition for light. The plants that were pruned earlier had fewer buds, which resulted in a lower number of stems. However, the stems had a higher average weight and diameter because of the lower light competition in the first cycle. In the second cycle, the differences between the pruning times were reduced. However, the late pruning still resulted in the harvesting of more packs and a higher yield.

Generally speaking, the growth (Tab. 2) and productivity responses (Tab. 4), as well as the length of the flower stems (Tab. 4), were lower in the second productive cycle. In the first productive cycle, the plant growth occurred in the spring. The mild temperatures 
and the increased availability of solar radiation, typical of this season in Rio Grande do Sul State, promoted the plant growth and production of harvested stems. In the second cycle, the growth occurred from mid-January to April, when the very high temperatures in the first months and the decline in solar radiation, characteristic of the summer-autumn period, reduced plant growth and production.

\section{CONCLUSIONS}

The $100 \%$ raw rice husk substrate resulted in lower plant growth, flower stem production and quality. However, the rice husk-based substrates did not affect the dry matter partitioning between flowers and vegetative organs or the balance between the shoot and root growth. The substrates with $100 \%$ carbonized rice husks and the mixture of raw rice husks $(85 \%)+$ compound S10 (15\%) may be indicated for the cultivation of gypsophila in a closed system.

The late pruning increased the growth and productivity of the gypsophila, benefiting the flower stem quality with regard to length.

The gypsophila crop adapted well to the cultivation in gutters filled with rice husk-based substrates in a leaching recirculation system.

Conflict of interests: the manuscript was prepared and reviewed with the participation of the authors, who declare that there exists no conflict of interest that puts the validity of the presented results at risk.

\section{BIBLIOGRAPHIC REFERENCES}

Andriolo, J.L., D.I. Jänisch, C.S. Oliveira, C. Cocco, O.J. Schmitt, and F.L. Cardoso. 2009. Cultivo sem solo do morangueiro com três métodos de fertirrigação. Ciênc. Rural 39(3), 691-695. Doi: 10.1590/ S0103-84782009005000009

Da Costa, J.C.F., R.M.N. Mendonça, L.F. Fernandes, F.P. Oliveira, and D. Santos. 2017. Caracterização física de substratos orgânicos para o enraizamento de estacas de goiabeira. Rev. Bras. Agropecu. Sustent. 7(2), 16-23. Doi: 10.21206/rbas.v7i2.390

Dorajeerao, A.V.D. and A.N. Mokashi. 2013. Growth analysis as influenced by pinching time in garland chrysanthemum (Chrysanthemum coronarium L.). Global J. Bio-Sci. Biotechnol. 2(1), 242-247.

Ferreira, E.A., M. Pasqual, V. Mendonça, and N.F. Pires. 2008. Influencia de diferentes substratos e fertilizantes na aclimatação de plantas de figueira (Ficus Carica L.). Rev. Caatinga 21(5), 64-68.

Ibraflor (Instituto Brasileiro de Floricultura). 2016. Critério de classificação Gypsophila paniculata. In: http:// www.ibraflor.com/publicacoes/vw.php? $\operatorname{cod}=163$; consulted: October, 2017.

Girardi, L.B., M.X. Peiter, R.A. Bellé, F.A. Backes, F.S. Soares, and I. Valmorbida. 2012. Disponibilidade hídrica e seus efeitos sobre o desenvolvimento radicular e a produção de Gypsophila envasada em ambiente protegido. Irriga 17, 501-509. Doi: 10.15809/irriga.2012v17n4p501

Medeiros, C.A.B., A.S. Strassburger, and L.E.C. Antunes. 2008. Casca de arroz e sua carbonização para utilização em substratos. Circular Técnica. Embrapa Clima Temperado, Pelotas, Brazil.

Peil, R.M.N., A.A.R. Albuquerque Neto, and C.V. Rombaldi. 2014. Densidade de plantio e genótipos de tomateiro cereja em sistema fechado de cultivo em substrato. Hort. Bras. 32, 234-240. Doi: 10.1590/ S0102-05362014000200021

Petry, C., S. Bellé, and E.O. Calvete. 2008. Produção de gypsophila. pp. 172-178. In: Petry, C. (ed.). Plantas ornamentais aspectos para a produção. $2^{\text {nd }}$ ed. Editora Universidade de Passo Fundo, Passo Fundo-RS, Brazil.

Pires, R.C.M., P.R. Furlani, R.V. Ribeiro, D.B. Junior, E. Sakai, A.L. Lourenção, and A.T. Neto. 2011. Irrigation frequency and substrate volume effects in the growth and yield of tomato plants under greenhouse conditions. Sci. Agric. 68(4), 400-405. Doi: 10.1590/ S0103-90162011000400002

Sonneveld, C. and N. Straver. 1994. Nutrient solutions for vegetebles and flowers grown in water or substrates. $10^{\text {th }}$ ed. Series Voeding Soplossingen Glastuinbouw. Proefstation voor Tuinbouw onder Glas, Naaldwijk, The Netherlands.

Steffen, G.P.K., Z.I. Antiniolli, R.B. Steffen, and R.G. Machado. 2010. Cáscara de arroz y estiércol bovino como sustratos para la multiplicación de lombrices de tierra y la producción de plántulas de tomate y lechuga. Acta Zool. Mex. 26, 333-343.

Wahome, P.K., T.O. Oseni, M.T. Masarirambi, and V.D. Shongwe. 2011. Effects of different hydroponics systems and growing media on the vegetative growth, yield and cut flower quality of gypsophila (Gypsophila paniculata L.). World J. Agr. Sci. 7(6), 692-698. 